\title{
Study of Yield Contributing Characters of Mustard
}

\author{
Sangeeta Dwivedi* and Reeta Mishra \\ Upadhi (PG) Mahavidhyalay, Pilibhit (U.P.), India \\ RVSKVV-Krishi Vigyan Kendra, Morena (M.P.), India \\ *Corresponding author
}

\section{A B S T R A C T}

\section{Keywords}

Integrated nutrient management (INM), Mustard, Yield, Oil content, Fertilizer

Article Info

Accepted:

20 September 2020 Available Online: 10 October 2020
Mustard crop is mainly grown in the marginal/poor soils mainly under rainfed conditions with marginal inputs. A field investigation was carried out at Regional Agriculture Testing and Demonstration Station Bilwa, Bareilly district of Uttar Pradesh. The influence of fertilization on yield and quality on growth, yield and seed quality of mustard (Brassica juncea L.) cultivar Kranti was studied. Fifteen treatments consisting of 100, 75 and $50 \%$ of the recommended dose of fertilizers (RDF) either alone or with successive addition of farmyard manure (FYM 10 t/ ha, sulphur @ $40 \mathrm{~kg} \mathrm{~S} / \mathrm{ha}$, zinc @25 kg ZnSO $/$ /ha, boron@ $1 \mathrm{~kg} / \mathrm{B} / \mathrm{ha}$ ) were tested. Application of $100 \%$ recommended dose of fertilizers along with farmyard manure resulted in maximum seed weight (16 g/plant), 1000-seed weight(4 g), seed yield (2070 Kg/ha) and oil yield (836 kg/ha). The maximum oil content (41.75 percent) was recorded in treatment $\mathrm{T} 15$. The variations in growth and yield between 100, 75 and $50 \%$ recommended dose of fertilizers with farmyard manure, were significant. Significantly higher oil content was recorded at $50 \%$ recommended dose of fertilizers with farmyard manure, than over control. Hence, the application of recommended doses of sulphur, zinc, boron along with farm yard manure could be achieved for farmer's economic profit.

\section{Introduction}

Rapeseed-mustard (Brassica spp.) is one of the most important oilseed crops of the world where India is ranking third in area and production in the world (DRMR, 2050). The genus Brassica of family Cruciferae (Brassicaceae) is consisted of several multipurpose species which yield edible leaves, roots, stems and seeds as spice. Brassicas are also extensively cultivated as cash crop, vegetables and fodder. Brassicas are generally grown in northern and western parts of India or in the world above $200 \mathrm{~N}$ of latitude. Oleiferous Brassicas are important rabi (post-rainy) season oil seed crops in India and occupies a premier position due to its high oil content. Seeds of Brassicas are used for various purposes. Rapeseeds are rich in oil and proteins. The oil content varies from 3639\% per seed (Yadav et al., 2013).

The seed and oil of mustard are used as a condiment in the preparation of pickles, 
flavouring curries and vegetables as well as for cooking and frying purposes. Its oil is used in many industrial products, cake as cattle feed and manure and green leaves for vegetable and green fodder (Meena et al., 2013).

Horticultural crops, mainly vegetable and leafy crops, management practices include the heavy application of chemical fertilizers which become inevitable due to the depletion of soil organic matter. The extensive use of chemical fertilizers in these crops deteriorated soil health that in turn affected productivity (Chaudhari et al., 2019). The Indian soils have generally been reported to be low in nitrogen, phosphorus and sulphur because of the multiple cropping and introduction of high yielding varieties, and the deficiency of these nutrients in soil becoming wider. Fertilizer plays an important role in plant growth and shows a significant increase in yield (Singh et al., 2017).

Therefore, an integrated nutrient management (INM) is the most efficient and practical way to mobilize all the available, accessible, and affordable plant nutrient sources to optimize the productivity of the crops/cropping systems and economic return to the farmer. Thus the main aim of this research is to obtain maximum efficiency of fertilization on yield and quality on growth, yield and seed quality of mustard (Brassica juncea l.) cultivar Kranti.

\section{Materials and Methods}

The present investigation was conducted to study various yield contributing characters of oleiferous Brassicas. To study the impact of fertilization on yield and quality of Indian mustard, a field experiment was conducted at Regional Agriculture Testing and Demonstration Station Bilwa, Bareilly district of Uttar Pradesh.
The soil of the experimental field belonged to sandy loam. Since the field crops are greatly influenced by the phases of soil series. Thus the composite soil samples from the $0-15 \mathrm{~cm}$ and $15-30 \mathrm{~cm}$ depths were collected, air dried and processed and used for chemical analysis before sowing. Soil having low to medium fertility status with low organic content, available $\mathrm{N}$, available $\mathrm{P}$ and available $\mathrm{S}$ were in low range, available $\mathrm{K}$ was medium in range, hot water soluble $\mathrm{B}$ and DTPA extractable $\mathrm{Zn}$ in optimum range and neutral to slightly alkaline in nature (Table 1).

Field experiment was conducted in randomized block design with three replications. The treatments comprising of 15 different integrated plant nutrient management practices. The other details are as under-

\begin{tabular}{|l|l|}
\hline Variety & Kranti \\
\hline Gross plot size & $4.2 \mathrm{~m} \times 3.5 \mathrm{~m}$ \\
\hline Net plot size & $3.0 \mathrm{~m} \times 2.5 \mathrm{~m}$ \\
\hline Row to row spacing & $30 \mathrm{~cm}$ \\
\hline Plant to plant spacing & $15 \mathrm{~cm}$ \\
\hline No. of rows per plot & 14 \\
\hline $\begin{array}{l}\text { No. of rows harvested per } \\
\text { plot }\end{array}$ & 10 \\
\hline
\end{tabular}

The experiment consisted of fifteen treatments viz., T1- Control, T2 -100\% RDF + FYM 10 t/ha, T3 - $100 \%$ RDF + FYM 10 t/ ha + sulphur@40kg S/ha, T4 - 100\% $\mathrm{RDF}+\mathrm{FYM} 10 \mathrm{t} / \mathrm{ha}+$ sulphur @ $40 \mathrm{~kg}$ S/hat zinc @25 kg ZnSO 4 ha, T5- $100 \%$ $\mathrm{RDF}+\mathrm{FYM} 10 \mathrm{t} / \mathrm{ha}+$ sulphur @ $40 \mathrm{~kg}$ S/ha+ zinc@25 kg ZnSO $4 /$ ha+ boron@1kg/ B/ha, T6 -75\% of Recommended fertility, T7$75 \%$ of Recommended fertility++ FYM 10 t/ha, T8-75\% RDF + FYM 10 t/ ha + sulphur @ $40 \mathrm{~kg} \mathrm{~S} / \mathrm{ha}, \mathrm{T} 9-75 \% \mathrm{RDF}+\mathrm{FYM} 10$ t/ ha 
+ sulphur @ 40 kg S/ha+ zinc @25 kg $\mathrm{ZnSO}_{4} / \mathrm{ha}, \mathrm{T} 10-75 \% \mathrm{RDF}+\mathrm{FYM} 10 \mathrm{t} / \mathrm{ha}+$ sulphur @40 kg S/hat zinc @25 kg $\mathrm{ZnSO}_{4} / \mathrm{ha}+$ boron@1kg/ B/ha, T11-50\% of Recommended fertility, T12-50\% of Recommended fertility++ FYM 10 t/ha, T13$50 \%$ RDF + FYM $10 \mathrm{t} / \mathrm{ha}+$ sulphur @ $40 \mathrm{~kg}$ S/ha, T14-50 \% RDF + FYM 10 t/ ha + sulphur @40 kg S/hat zinc @25 kg $\mathrm{ZnSO}_{4} / \mathrm{ha}$ and T15- $50 \% \mathrm{RDF}+\mathrm{FYM} 10 \mathrm{t} /$ ha+sulphur@40 kg S/ha+ zinc @25 kg $\mathrm{ZnSO}_{4} / \mathrm{ha}+$ boron@ $1 \mathrm{~kg} / \mathrm{B} / \mathrm{ha}$ laid out in randomized block design with three replications.

The sources of nitrogen, phosphorus and potassium were urea, diammonium phosphate and muriate of potash. The sources of sulphur and zinc were gypsum and zinc sulphate while borax was used as a source of boron. Full doses of FYM, phosphorus, potassium, sulphur, zinc, boron and half dose of nitrogen was applied at the time of sowing. Rest half dose of nitrogen was top dressed in two splits, one after first irrigation and second at square leaf stage.

For recording growth character, seed weight, 1000 -seed weight, seed yield, oil content and oil yield were recorded. The seeds obtained after threshing the siliquae from five randomly selected plants were weighed and reported on per plant basis in $\mathrm{g}$. The weight of 1000 -seeds was recorded in $\mathrm{g}$ after counting the seeds.

Seed samples from all branches were collected and analyzed for oil content (\%) in seeds. Oil yield was calculated by multiplying seed yield and oil content in the seeds.

From the individual plot, net plot area was harvested, air dried and produce was threshed and cleaned. The final weight was recorded in $\mathrm{kg}$ per plot and converted into $\mathrm{kg}$ per hectare.
The experiment data obtained during the course of study were subjected to statistical analysis by applying the technique of analysis of variance (ANOVA) prescribed for the randomized block design (RBD) to test the significance of the overall differences among treatments by the ' $\mathrm{F}$ ' test and conclusion were drawn at 5 percent probability level. When the ' $F$ ' value from analysis of variance tables was found to be significant, the critical difference (C.D.) was computed to test the significance of the difference between the two treatments.

\section{Results and Discussion}

\section{Seed weight}

The mean seed weight per plant was 11.74 $\mathrm{g} /$ plant. The integrated plant nutrient management practices significantly influenced the seed weight per plant. The highest seed weight per plant $16 \mathrm{~g}$ was recorded in treatment T5 which was significantly higher than rest of the treatments (Table 2). The lowest seed weight (7.7 $\mathrm{g} /$ plant) was recorded in treatment T11 where $50 \%$ recommended fertility was applied followed by the treatment in which $75 \%$ recommended fertility was applied.

The addition of supplementary ingredients to different fertility levels increased the total seed weight per plant. Significantly maximum seed weight was recorded in those plots received all supplementary nutrients with different levels of fertility. All the supplementary nutrients with different levels of fertility gave significant more total seed weight per plant. Addition of FYM+ S to $100 \%$ recommended fertility resulted in significantly higher total seed weight over T1 per plant. The positive effect of supplementary nutrients on yield attributes of Indian mustard was observed by Singh and Pal (2011). 


\section{0-seed weight}

A average 1000-seed weight recorded was 3.8 $\mathrm{g}$ during the study. Difference in integrated plant nutrient management practices significantly influenced the average 1000seed weight. The highest average 1000-seed weight was recorded in treatment T5 (Table $2)$. The lowest 1000 -seed weight (3.5 g/plant) was recorded in treatment T11 where $50 \%$ recommended fertility was applied followed by the treatment in which $75 \%$ recommended fertility was applied. Successive addition of supplementary ingredient to different fertility levels resulted in increase in average 1000seed weight and maximum was attained when all the ingredients were added. The higher value of yield attributes is the result of higher nutrient levels resulted in to better growth and more translocation of photosynthates from source to sink as reported by Rana et al. (2005) and Tripathi et al. (2010).

\section{Seed yield}

Seed yield is a quantitative trait, which is the expression of the result of genotype, environmental effect and genotype environment interaction (Angadi et al., 2003). The number of siliquae per plant is the most important component of the seed yield in rapeseed mustard (Gunasekera et al., 2006).

The average seed yield was $1438 \mathrm{~kg} / \mathrm{ha}$. Difference in integrated plant nutrient management practice significantly influenced the seed yield. The highest seed yield was recorded at treatment T5 (Table 2). The seed yield at T5 was significantly higher than rest of the treatments. In general, seed yield was reduced with reduction in recommended fertility.

Successive addition of supplementary ingredients to different fertility levels resulted in increase of seed yield. Highest seed yield was attained when all the ingredients were added to respective fertility levels (T5, T10 and T15). The seed yield increased with the increase in level of RDF (Shukla et al., 2002 and Singh and Pal, 2011). Seed yield also increased with increase in $\mathrm{N}, \mathrm{P}$ and $\mathrm{K}$ rates (Mozaffari et al., 2012, Premi and Kumar, 2004 and Shekhawat et al., 2012).

\section{Oil content and oil yield}

In general, oil content decreased with increase in fertilizer levels while further increase was response of supplementary ingredients on seed recorded with addition of organic sources of nutrient supply. In the present study, the average oil content was $40.28 \%$. The difference in integrated plant nutrient management practices significantly influenced the oil content in seeds. The successive increase in fertility levels decreased the oil content in seeds obtained from main shoot, primary and secondary branches. Different treatments at $100 \%$ recommended fertility resulted in the lowest oil content among different fertilizer levels tested

Successive increase in supplementary ingredients resulted in increase in oil content in the seeds and the highest oil content was recorded at treatments T15 and in general T10 (Table 3). The above treatments were significantly higher than rest of the treatments.

Oil yield is mainly a function of seed yield. The oil yield was $578.26 \mathrm{~kg} / \mathrm{ha}$. Difference in integrated plant nutrient management practices significantly influenced the oil yield. Successive increase in fertility levels and addition of supplementary ingredients increased the oil yield. In general, highest oil yield was $(836 \mathrm{~kg} / \mathrm{ha})$ was recorded with the treatment T5 (Table 3). The highest oil yield was significantly higher than oil yield obtained at all the treatments. 
Table.1 Initial physico-chemical properties of the experimental site

\begin{tabular}{|l|c|}
\hline Soil properties & Value \\
\hline Textural class & Sandy loam \\
\hline Organic carbon (\%) & 0.29 \\
\hline Total nitrogen (\%) & 0.083 \\
\hline Available nitrogen (kg/ha) & 185.0 \\
\hline Available sulphur (ppm) & 11.76 \\
\hline Available phosphorus (kg P/ha) & 9.0 \\
\hline Available potassium (kg K/ha) & 156.0 \\
\hline pH (1:2.5 Soil: Water & 7.5 \\
Suspension) & 7.5 \\
\hline CEC (cmol (p+) kg soil & 2.8 \\
\hline Available zinc (ppm) & 0.66 \\
\hline Available boron (ppm) & \\
\hline
\end{tabular}

Table.2 Seed weight (g/plant), 1000 seed weight (g) and seed yield (Kg/ha) as influenced by plant nutrient management in Brassica juncea

\begin{tabular}{|c|c|c|c|c|}
\hline Symbol & Treatment & Seed weight & $\begin{array}{c}1000 \text { seed } \\
\text { weight }\end{array}$ & Seed yield \\
\hline $\mathbf{T 1}$ & Recommended fertility (RF) & 11.10 & 3.7 & 1560 \\
\hline $\mathbf{T} 2$ & T1+FYM 10 t/ha & 11.70 & 3.9 & 1626 \\
\hline T3 & T2+Sulphur@40kg S/ha & 14.00 & 3.9 & 1850 \\
\hline T4 & T3+Zinc@25 kg ZnSO $/$ /ha & 15.60 & 4.0 & 1970 \\
\hline T5 & T4+Boron@1kg/B/ha & 16.00 & 4.0 & 2070 \\
\hline T6 & $75 \%$ of Recommended fertility & 9.30 & 3.6 & 1375 \\
\hline T7 & T6+ FYM 10 t/ha & 11.60 & 3.7 & 1425 \\
\hline T8 & T7+Sulphur@ @ 40 kg S/ha & 12.60 & 3.8 & 1455 \\
\hline T9 & T8+Zinc@25 kg ZnSO $4 / \mathrm{ha}$ & 13.20 & 3.8 & 1460 \\
\hline T10 & T9+Boron@1kg/B/ha & 13.60 & 3.9 & 1558 \\
\hline T11 & $50 \%$ of Recommended fertility & 7.70 & 3.5 & 975 \\
\hline T12 & T11+ FYM 10 t/ha & 9.00 & 3.6 & 1000 \\
\hline T13 & T12+Sulphur@40kg S/ha & 9.60 & 3.9 & 1006 \\
\hline T14 & T13+Zinc@25 kg ZnSO $4 /$ ha & 10.40 & 3.9 & 1084 \\
\hline T15 & T14+ Boron@1kg/B/ha & 10.70 & 3.9 & 1160 \\
\hline & SEM \pm & 0.11 & 0.18 & 2.22 \\
\hline & CD at $5 \%$ & 0.32 & 0.52 & 6.43 \\
\hline
\end{tabular}


Table.3 Oil content (\%) and oil yield (kg/ha) in the seeds of Brassica juncea as influenced by plant nutrient management

\begin{tabular}{|l|l|c|c|}
\hline \multicolumn{1}{|c|}{ Symbol } & \multicolumn{1}{|c|}{ Treatment } & Oil content & Oil yield \\
\hline T1 & Recommended fertility (RF) & 38.90 & 607 \\
\hline T2 & T1+FYM 10 t/ha & 39.15 & 636 \\
\hline T3 & T2+ Sulphur @ 40 kg S/ha & 39.70 & 734 \\
\hline T4 & T3+Zinc @25 kg ZnSO $/$ ha & 39.90 & 786 \\
\hline T5 & T4+Boron@ 1 kg/ B/ha & 40.40 & 836 \\
\hline T6 & 75\% of Recommended fertility & 39.15 & 538 \\
\hline T7 & T6+ FYM 10 t/ha & 39.90 & 568 \\
\hline T8 & T7+ Sulphur @ 40 kg S/ha & 40.60 & 591 \\
\hline T9 & T8+Zinc @ 25 kg ZnSO $/$ ha & 40.90 & 597 \\
\hline T10 & T9+ Boron@ 1 kg/ B/ha & 41.45 & 646 \\
\hline T11 & 50\% of Recommended fertility & 39.80 & 388 \\
\hline T12 & T11+FYM 10 t/ha & 40.32 & 403 \\
\hline T13 & T12+ Sulphur @ 40 kg S/ha & 40.90 & 411 \\
\hline T14 & T13+Zinc @ 25 kg ZnSO $/$ /ha & 41.40 & 449 \\
\hline T15 & T14+ Boron@ 1 kg/ B/ha & 41.75 & 484 \\
\hline & SEM \pm & 0.02 & 1.89 \\
\hline & CD at 5\% & 0.05 & 5.49 \\
\hline
\end{tabular}

The increase in oil content with sulphur fertilization may be attributed to its role in oil synthesis (Tripathi et al., 2010), increase in glucosides (Kumar et al., 2006 and Singh et $a l ., 2010)$. Increase in availability of sulphur attribute to increased conversion of fatty acid metabolites to the end products of fatty acids as supported by Tripathi et al., (2010) and Singh and Pal (2011). Increase in oil content on potassium application is attributed to increase in the activity of enzymes involved in fat synthesis (Singh et al., 2010). Positive effect of sulphur along with phosphorus and other nutrients on oil content is because of phosphorus as it is a constituent of phospholipids and also essential for oil synthesis (Kumar and Yadav, 2007).

In conclusions, highest seed weight per plant $(16 \mathrm{~g})$ was recorded when all the supplementary ingredients (T5) were added to
100 percent recommended fertilizer level which was significantly higher than rest of the treatments. The 1000-seed weight was significantly influenced by addition of supplementary ingredients. The application of all the supplementary ingredients increased 1000-seed weight (4 g) over no supplementation. The seed yield was significantly influenced by the integrated plant nutrient management practices. The increase in recommended fertilizer level increased the seed yield and maximum seed yield was recorded when 100 percent recommended fertilizer was applied. Successive addition of supplementary ingredients to 100,75 and 50 percent recommended fertilizer levels increased the seed yield by $32.69,13.31$ and 18.97 percent over no supplementation to respective fertilizer levels. the overall highest seed yield $2070 \mathrm{~kg} / \mathrm{ha}$ was recorded when all the 
supplementary ingredients were added to 100 percent recommended fertility levels.

On the basis of results drawn, it may be recommended that the application of $100 \%$ recommended fertility along with farmyard manure, sulphur, zinc and boron resulted in maximum seed weight, 1000-seed weight and seed yield in treatment T5. The maximum oil content was recorded in treatment T15 and maximum oil yield was recorded in treatment T5. Hence, the use of recommended doses of sulphur, zinc, boron along with farm yard manure could be able to achieve the best profit to farmer's community.

\section{References}

Angadi, S. V., Cufprth, H. W., Mc Conkey, B. B., Gan , Y. 2003. Yield adjustment by canola grown at different plant population under semiarid conditions. Crop Science, 43: 1358-1360.

Chaudhari Dipendra, Shree Prasad Vista, Prabin Ghimire, et al., 2019. Influence of agricultural lime in alleviating acidity level of various acid soils. World J Agri \& Soil, 3(3).

D.R.M.R., Vision 2050. Directorate of Rapeseed-Mustard Research, Bharatpur, Rajasthan.:2. http://www.icar.org.in/vision\%202050 \%20DRMR\% 20Rajasthan.pdf (2015).

Gunasekera, C.P., Martin, L. D, Siddique, K.H.M., Walton, G.H. 2006. Genotype by environment interactions of Indian mustrad (Brassica juncea L.) and Rapeseed (B. napus L.) in Mediteranneantype environments. Crop growth and seed yield. European Journal of Agronomy, 25: 1-12.

Kumar, H. and Yadav, D. S. 2007. Effect of phosphorus and sulphur levels on growth, yield and quality of Indian mustard (Brassica juncea L.) cultivars. Indian J. Agron., 55(2): 154-157.
Kumar, N., Singh, S. and Singh, V. 2006. Effect of iron and sulphur levels on yield, oil content and their uptake by Indian mustard (Brassica juncea). Indian J. Agron., 51(1): 63-64.

Meena, D. R., Chauhan, J. S., Singh, M., Singh, K. H. and Meena, M. L. 2013. Genetic variation and correlations among physiological characters in Indian mustard (Brassica juncea L.) under high temperature stress. Indian Journal of Genetics, 73(1): 101-104.

Mozaffari, S. N., Delkhosh, B. and Rad, A. S. 2012. Effect of nitrogen and potassium levels on yield and some of the agronomical characteristics in Mustard (Brassica juncea). Indian J. Sci. Technol, 5(2): 2051-2054.

Premi, O. P. and Kumar, M. 2004. Response of Indian mustard (Brassica juncea) to different levels of nitrogen and phosphorus under irrigated condition. Indian J. Agric. Res., 38(2): 151-153.

Rana, K. S., Rana, D.S. and Gautam, R. C. 2005. Influence of phosphorus, sulphur and boron on growth, yield, nutrient uptake and economics of Indian mustard (Brassica juncea) under rainfed conditions. Indian $\mathrm{J}$. Agron, 50(4): 314-316.

Shekhawat, K., Rathore, S. S., Premi, O. P., Kandpal, B. K. and Chauhan, J. S. 2012. Advances in agronomic management of Indian mustard (Brassica juncea (L.) Czern. Coss.): An overview. Hindawi Publishing Corporation. International Journal of Agronomy. pp. 6-9.

Shukla, R. K., Kumar, A., Mahapatra, B. S. and Kandpal, B. 2002. Integrated nutrient management practices in relation to morphological and physiological determinants of seed yield in Indian mustard (Brassica juncea). Indian J. Agric. Sci., 72(11): 670-672. 
Singh, A.K., Singh, S.H., Alam, S., Rai, O.P., Singh, G. 2017. Effect of sowing dates and varieties on quality and economics of Indian mustard (Brassica juncea $L$.). International Journal of Current Microbiology and A. Science, 6(3): 799-802.

Singh, S. P. and Pal, M. S. 2011. Effect of integrated nutrient management on productivity, quality, nutrient uptake and economics of mustard (Brassica juncea). Indian J. Agron, 56(4): 381387.

Singh, Y., Singh, T., Singh, U. N. and Rajput, P. K. 2010. Effect of nutrient management on yield, quality and economics of irrigated Indian mustard (Brassica juncea). Indian J. Agric.
Sci., 80(8): 691-694.

Tripathi, M. K., Chaturvedi, S., Shukla, D. K. and Mahapatra, B. S. 2010. Yield performance and quality in Indian mustard (Brassica juncea) as affected by integrated nutrient management. Indian J. Agron., 55(2): 138-142.

Yadav, S.K., Yadava, D.K., Vasudev, S., Yadav, S., Kumar, P.R., and Nigam, R. 2013. Assessment of seed quality and oil content in different branches of Indian mustard (Brassica juncea) cultivars at different storage intervals. Indian Journal of Agricultural Sciences, 83: 227-233.

\section{How to cite this article:}

Sangeeta Dwivedi and Reeta Mishra. 2020. Study of Yield Contributing Characters of Mustard. Int.J.Curr.Microbiol.App.Sci. 9(10): 2503-2510. doi: https://doi.org/10.20546/ijcmas.2020.910.300 